\title{
Study on the Interaction between CaO-based Sorbents and Coal Ash in Calcium Looping Process
}

Donglin He ${ }^{a}$, Changlei Qin ${ }^{a, *}$, Vasilije Manovic ${ }^{b}$, Jingyu Ran $^{a}$, and Bo Feng ${ }^{c}$

${ }^{a}$ Key Laboratory of Low-grade Energy Utilization Technologies and Systems of Ministry of Education, College of Power Engineering, Chongqing University, Chongqing 400044, China

${ }^{\mathrm{b}}$ Combustion and CCS Centre, Cranfield University, Cranfield, Bedfordshire MK43 0AL, United Kingdom

${ }^{c}$ School of Mechanical and Mining Engineering, The University of Queensland, St Lucia, Queensland 4072,

Australia

Published by Elsevier. This is the Author Accepted Manuscript issued with:

Creative Commons Attribution Non-Commercial No Derivatives License (CC:BY:NC:ND 3.0).
The final published version (version of record) is available online at http://dx.doi.org/10.1016/j.fuproc.2016.09.017 Please refer to any applicable publisher terms of use.

* Corresponding author:

Tel.: +86-23-65103114. Email: c.qin@cqu.edu.cn. 


\begin{abstract}
Calcium looping (CaL), implemented via cyclic carbonation and calcination of calcium-based sorbents, is a novel and promising technology in reducing emissions of $\mathrm{CO}_{2}$ into the atmosphere. The reactivity of $\mathrm{CaO}$ is important in calcium looping, but its $\mathrm{CO}_{2}$ sorption will be affected by the presence of ash deriving from coal combustion in the calciner. We report here, the investigation of influence of coal-derived ash on $\mathrm{CaO}$-based sorbents using a thermogravimetric analyzer and a combination of other techniques. As a result of this work, our understanding of the role of several key variables (sorbent type, ash content and its particle size, the calcination conditions) and how they interact during repeated cycles of $\mathrm{CO}_{2}$ sorption and desorption, has been greatly enhanced. Furthermore, an attempt was made to explain the interaction mechanism between sorbents and coal-derived ash. It is proposed that the blockage of pores blow $3 \mathrm{~nm}$ due to ash deposition and subsequent grains agglomeration are the main reason for CaO-based sorbents' loss in $\mathrm{CO}_{2}$ carrying capacity.
\end{abstract}

Key words: calcium looping; $\mathrm{CO}_{2}$ capture; cyclic carbonation and calcination 


\section{INTRODUCTION}

The mitigation of anthropogenic $\mathrm{CO}_{2}$ emission has become a major concern due to the well-known problem of global warming. $\mathrm{CO}_{2}$ capture and sequestration (CCS) is an an option for reducing emissions of $\mathrm{CO}_{2}$ into atmosphere, especially via its implementation on fossil fuel-fired power plants. These plants are large stationary $\mathrm{CO}_{2}$ emission sources and inherently possess the technical potential for $\mathrm{CO}_{2}$ capture due to the relatively high $\mathrm{CO}_{2}$ concentration (10-15 vol. \%) [1-4]. However, separation of $\mathrm{CO}_{2}$ from power plants via conventional methods imposes severe energy penalties, and reduces the net electricity output by as much as 13-37\% [5-7]. Thus, a more technically and economically feasible $\mathrm{CO}_{2}$ separation process is required.

Calcium looping $(\mathrm{CaL})$ is an emerging $\mathrm{CO}_{2}$ capture technology based on the reversible reaction between $\mathrm{CaO}$ and $\mathrm{CO}_{2}$, and appears to be suitable for controlling $\mathrm{CO}_{2}$ emissions from fossil fuel-fired power plants. A schematic representation of $\mathrm{CaL}$ process for $\mathrm{CO}_{2}$ capture in a power plant is shown in Figure 1. $\mathrm{CO}_{2}$ in flue gas is sequestered through a carbonation reaction in a carbonator, then the sorbent containing $\mathrm{CO}_{2}$ is transported into a second reactor (calciner) and regenerated in an atmosphere of nearly pure $\mathrm{CO}_{2}$, producing a highly enriched stream of $\mathrm{CO}_{2}$. Repeated cycles the above processes results in sequestration of $\mathrm{CO}_{2}$ from the plant's flue gas. Comparing $\mathrm{CaL}$ to other $\mathrm{CO}_{2}$ capture technologies, calcium looping is particularly competitive due to (a) the abundant use of an inexpensive raw material (limestone) as sorbents, (b) the superior theoretical $\mathrm{CO}_{2}$ carrying capacity, (c) implementation using large-scale demonstrated fluidised-bed technology, and (d) the potentially wide application in both pre- and post-combustion $\mathrm{CO}_{2}$ capture systems. As a result, the calcium looping process has attracted great interest and had a rapid development in various areas worldwide. For example, various strategies including: hydration or thermal pretreatment of limestone-derived $\mathrm{CaO}$, development of sintering-resistant pure $\mathrm{CaO}$, and dispersion of active $\mathrm{CaO}$ on inert matrix etc., have been proposed to resolve the well-known loss-in-capacity problem of 
CaO-based sorbents [8-19]. Additionally, a number of pilot plants using the technology have been constructed [20-25], and the latest validation and operation of these facilities can be found in the scientific literature [26-29].

Figure 1. Schematic representation of calcium looping for $\mathrm{CO}_{2}$ capture from power plant flue gas.

Practically, the decomposition of $\mathrm{CaCO}_{3}$ is a highly endothermic reaction. To allow the collection of concentrated $\mathrm{CO}_{2}$ from calciner, combustion of coal with pure oxygen should be used to supply the large amount of energy required. However, direct contact between sorbents and coal ash would necessarily occur as a result of the simultaneous coal combustion and $\mathrm{CaCO}_{3}$ decomposition in the calciner. It is known that adhesion of coal ash to the surface of CaO-based sorbents under high temperature can affect characteristics of $\mathrm{CaO}$ for $\mathrm{CO}_{2}$ capture during repeated cycles of carbonation and calcination [30-34]. In the operation of a pilot-scale dual-fluidised bed for $\mathrm{CO}_{2}$ capture with oxygen-combustion in the calciner, Lu et al.[4] and Hughes et al.[35] observed the distribution of fine grains or a thin shell on the surface of calcined limes, which was attributed to ash deposition. Conversely, the work of Fan et al.[34] showed that $\mathrm{CO}_{2}$ sorption stability of the mixed limestone and coal ash was qualitatively similar to that of pure limestone with the cycle number. Kuramoto et al.[36] also investigated the effect of coal-derived minerals on $\mathrm{CO}_{2}$ sorption performance of $\mathrm{CaO}$-based sorbents, but their focus was on the carbonation reaction with elevated pressure, which was specifically suitable for hydrogen production from coal gasification. While similar performance between $\mathrm{CaCO}_{3}$ and $\mathrm{CaCO}_{3} /$ ash was demonstrated in the calcination/carbonation cycle, solid-solid interaction between the materials was observed to be largely enhanced by an intermediate hydration treatment. It was suggested that a proper choice of coal particle size and reaction conditions may reduce the interaction. 
Based on the above results, it is known that the presence of coal ash can limit the $\mathrm{CO}_{2}$ capture by $\mathrm{CaO}$-based sorbents. However, no consensus has been reached on when and how coal-derived ashes are involved; i.e., whether the characteristics of $\mathrm{CaO}$-based sorbents would be a key factor for the sorption performance with the addition of coal-derived ash. On the other hand, the interaction mechanism of ash on the sorption process of sorbents is still unclear. Therefore, purpose of the work was to evaluate the impacts of different coal ashes on $\mathrm{CO}_{2}$ sorption by both natural and synthetic $\mathrm{CaO}$-based sorbents under various testing conditions, and then understand the interaction mechanism between coal ashes and CaO-based sorbents.

\section{EXPERIMENTAL SECTION}

\subsection{Materials and Sample Preparation}

In this work pure lime and a synthetic sorbent (SolGel) were used as both sorbents and components in the mixtures with coal ash. The lime (denoted as "L" in the mixture with coal ash) was prepared by calcining a natural limestone from Dujiangyan, China, at $950{ }^{\circ} \mathrm{C}$ for $30 \mathrm{~min}$; its mass loss during calcination was equal to $39.64 \%$. The fresh lime was sieved to obtain a sample with particles size smaller than $0.1 \mathrm{~mm}$. SolGel (denoted as "S" in the mixture), consisting of $75 \mathrm{wt}$ \% $\mathrm{CaO}$ and 25 wt. \% $\mathrm{MgO}$, was synthesized from analytical reagents of calcium nitrate tetrahydrate $(\geqslant 99.0 \%)$, magnesium nitrate hexahydrate $(\geqslant 99.0 \%)$, and citric acid monohydrate $(\geqslant 99.5 \%)$ following procedures described in Ref. [8]. Firstly, predetermined amounts of $\mathrm{Ca}\left(\mathrm{NO}_{3}\right)_{2} \cdot 4 \mathrm{H}_{2} \mathrm{O}$, $\mathrm{Mg}\left(\mathrm{NO}_{3}\right)_{2} \cdot 6 \mathrm{H}_{2} \mathrm{O}$, and citric acid were added into deionized water at a water to metal ions molar ratio of 40:1 and a citric acid to metal ions molar ratio of 1:1. Then, the mixed solution was continuously stirred at $80{ }^{\circ} \mathrm{C}$ for $7 \mathrm{~h}$ to form a well-dispersed sol. Thirdly, the sol was kept at room temperature for $18 \mathrm{~h}$ to form wet gel, followed by a two-stage drying of $5 \mathrm{~h}$ at $80{ }^{\circ} \mathrm{C}$ and $12 \mathrm{~h}$ at $110{ }^{\circ} \mathrm{C}$ in an oven. Finally it was calcined at $900{ }^{\circ} \mathrm{C}$ for $30 \mathrm{~min}$ and sieved to be smaller than $0.1 \mathrm{~mm}$ in particle 
size. Both natural lime and synthetic SolGel were stored in a desiccator before using.

Two different ashes were obtained by burning a bituminous coal from Xunyong (denoted as X) and an anthracitic coal from Yaan (denoted as $\mathrm{Y}$ ) at $950{ }^{\circ} \mathrm{C}$ for $4 \mathrm{~h}$. Afterwards they were sieved into five particle size ranges of $<0.1 \mathrm{~mm}, 0.1-0.2 \mathrm{~mm}, 0.2-0.3 \mathrm{~mm}, 0.3-0.4 \mathrm{~mm}$ and $0.4-0.5 \mathrm{~mm}$ before mixing with the lime and SolGel.

To study interaction characteristics between the $\mathrm{CaO}$-based sorbent and coal ash, these materials were fully mixed for $30 \mathrm{~min}$ in a mechanical agitator. The mixtures were denoted using abbreviations of $\mathrm{CaO}$-based sorbents and coal ashes, followed by the mass content of ash and its particle size range. For example, "LY30_0.1-0.2" represents the mixture of lime and Yaan coal ash with a coal ash content of $30 \mathrm{wt} . \%$ and ash particle size of 0.1 to $0.2 \mathrm{~mm}$.

\subsection{Sorption Test and Materials Characterisation}

$\mathrm{CO}_{2}$ carrying capacity of samples was evaluated using a NETZSCH Simultaneous Thermal Analyser (STA 409 PC). In a typical test under mild calcination conditions, a small (around $12 \mathrm{mg}$ ) sample was placed in a quartz pan and heated up to $900{ }^{\circ} \mathrm{C}$ at a rate of $25{ }^{\circ} \mathrm{C} / \mathrm{min}$ under a flow of 85 $\mathrm{mL} / \mathrm{min} \mathrm{N}_{2}$; the calcination temperature was held for $10 \mathrm{~min}$. Then the sample was cooled to $650{ }^{\circ} \mathrm{C}$ at a rate of $-25{ }^{\circ} \mathrm{C} / \mathrm{min}$. Once carbonation temperature was reached, a $\mathrm{CO}_{2}$ flow of $15 \mathrm{~mL} / \mathrm{min}$ was introduced into the STA. Thus, the carbonation reaction was performed in an atmosphere containing 15 vol. $\% \mathrm{CO}_{2}$ and 85 vol. $\% \mathrm{~N}_{2}$. After $10 \mathrm{~min}$ carbonation, the flow of $\mathrm{CO}_{2}$ was stopped, completing one cycle of calcination and carbonation. The calcination/carbonation cycle was repeated 15 times for each sample. Some tests were carried out under more severe calcination condition, i.e. at $950{ }^{\circ} \mathrm{C}$ in an atmosphere of pure $\mathrm{CO}_{2}$, but the other testing conditions were kept unchanged.

$\mathrm{CO}_{2}$ carrying capacity of $\mathrm{CaO}$ in the samples was expressed in the form of carbonation conversion. It was calculated from the continuously monitored weight changes during reactions, assuming mass change was only caused by the formation and decomposition of $\mathrm{CaCO}_{3}$. 
Table 1. Chemical composition of calcined limestone and coal ashes.

X-ray Fluorescence (XRF) measurements were used to determine the chemical composition of raw materials (Table 1). It was seen that both coal ashes have a similar chemical composition of the main components namely $\mathrm{SiO}_{2}, \mathrm{Al}_{2} \mathrm{O}_{3}$, and $\mathrm{Fe}_{2} \mathrm{O}_{3}$; on the contrary the lime was almost pure $\mathrm{CaO}$ (96.56 wt. \%). A X-ray Diffractometer (XRD) was used over the angular range $10-90^{\circ}$ in $0.02^{\circ}$ step size and $0.3 \mathrm{~s}$ per step at $40 \mathrm{kV}, 150 \mathrm{~mA}$. Sample phases morphologies were observed by a scanning electron microscope (TESCAN VEGA3) at an acceleration voltage of $10 \mathrm{kV}$. The surface area, pore volume and pore size distribution of materials were determined using a Micromeritics ASAP 2020 instrument. Prior to $\mathrm{N}_{2}$ adsorption/desorption analysis at approximately $-196{ }^{\circ} \mathrm{C}$, materials were outgassed at $350{ }^{\circ} \mathrm{C}$ for $4 \mathrm{~h}$. Brunauer-Emmett-Teller (BET) and Barrett-Joyner-Halenda (BJH) models were used to calculate the specific surface area and pore size distribution, respectively.

\section{RESULTS AND DISCUSSION}

\subsection{Cyclic CaO Carbonation in Presence of Ash}

The investigation of interactions between coal ash and $\mathrm{CaO}$-based sorbent was conducted by varying the type of both coal-derived ash and sorbent; it was expressed in terms of carbonation conversion as a function of cycle number under mild calcination conditions (Figure 2). Carbonation as a function of time for the $1^{\text {st }}$ and $15^{\text {th }}$ cycle was shown in Figure 3 . The particle size of coal ash was below $0.1 \mathrm{~mm}$ and its content in the mixture was kept constant at $30 \mathrm{wt}$. \%. For comparison, the performance of pure lime and SolGel for $\mathrm{CO}_{2}$ capture were also shown. As it can be seen, SolGel showed the highest initial carbonation conversion (0.64), compared to that for pure lime (0.54). However, as cycles progressed, carbonation conversion of both sorbents decreased, and after 15 
cycles the residual value was 0.27 and 0.20 , respectively. The average decay rate of the conversion with cycle number was $2.48 \%$ and $2.25 \%$ per cycle for SolGel and lime, respectively. Influence of coal-derived ash on the cyclic carbonation was demonstrated to be different for SolGel and lime. Though carbonation conversion of LY30_<0.1 is below that of pure lime for the entire test, deviation of their conversion values is comparatively small. In contrast, carbonation conversion of SolGel-mixed-Yaan coal ash was approximately 0.59 initially, being $8.54 \%$ lower than that without the addition of coal ash; moreover, its conversion decreased to around 0.22 , thus $20.4 \%$ lower at the end of 15 cycles of calcination/carbonation. The results indicate that the addition of coal ash can reduce carbonation conversion of SolGel to a more pronounced extent. Xunyong (X) coal ash was also mixed into the two sorbents in a test of their $\mathrm{CO}_{2}$ sorption performance. It was clear that Xunyong coal ash demonstrated a detrimental impact on sorbent reactivity identical to Yaan coal ash. An examination of the above results led us to conduct further experiments only on Yaan (Y) coal ash.

Figure 2. Repeated cycles of carbonation in presence of coal-derived ash (carbonation at $650{ }^{\circ} \mathrm{C}$ in 15 vol. $\% \mathrm{CO}_{2}$ for $10 \mathrm{~min}$, and calcination at $900{ }^{\circ} \mathrm{C}$ in pure $\mathrm{N}_{2}$ for $10 \mathrm{~min}$ ).

Figure 3. Carbonation as a function of time in the $1^{\text {st }}$ and $15^{\text {th }}$ cycle of $\mathrm{CaO}$-based sorbents with/without coal ash at $650{ }^{\circ} \mathrm{C}$ in 15 vol. $\% \mathrm{CO}_{2}$.

\subsection{Effect of Ash Content on Carbonation}

Samples composed of different contents of coal ash (Y) and SolGel or lime were prepared for investigating its influence on $\mathrm{CaO}$ reactivity in $\mathrm{CO}_{2}$ capture. Carbonation conversion of samples containing coal ash amounts ranging from $15 \mathrm{wt}$. \% to $60 \mathrm{wt}$. \% are plotted in Figure 4 . While the change of $\mathrm{CaO}$ conversion was small for lime/coal ash with increasing ash content, as shown in 
Figure 4 (a), Figure 4 (b) demonstrates an accelerated degradation rate on $\mathrm{CaO}$ conversion with the increase of ash content in the mixture prepared using SolGel. It can be observed that SolGel with 15 wt. \% coal ash showed the highest $\mathrm{CaO}$ conversion in the first carbonation (around 65\%), while the initial conversion of SY30_<0.1, SY45_<0.1, and SY60_<0.1 was 59\%, 55\% and 43\%, respectively. After 15 cycles of calcination/carbonation, the same tendency of decreasing carbonation conversion with increasing ash content was still apparent. SolGel containing no coal ash has the highest $\mathrm{CaO}$ conversion of $27 \%$ at the end of 15 cycles, followed by SY15_<0.1, SY30_<0.1 and SY45_<0.1, and SY60_<0.1, which demonstrated the minimum conversion of $11 \%$, about $59 \%$ lower than that of pure SolGel. These results indicate that the pure lime utilised in the work has a superior resistance to the influence of coal ash on its performance for $\mathrm{CO}_{2}$ sorption during multiple cycles of calcination/carbonation, while the $\mathrm{CO}_{2}$ sorption reactivity of SolGel can be severely inhibited by coal ash. Therefore, preliminary selection of CaO-based sorbent is important, as adaptability of sorbents in the real application environment could vary extensively. Though ash percentages from 15 wt. $\%$ to 60 wt. $\%$ were used in this work, it is necessary to know that the content of coal ash should be kept as low as possible in the practical calcium looping system, as more ash means larger heat consumption in the calciner.

Figure 4. Effect of ash content on carbonation. Testing condition: carbonation in 15 vol. $\% \mathrm{CO}_{2}$ at $650{ }^{\circ} \mathrm{C}$, calcination in 100 vol. $\% \mathrm{~N}_{2}$ at $900{ }^{\circ} \mathrm{C}$, both for $10 \mathrm{~min}$.

\subsection{Effect of Ash Particle Size on Carbonation}

The effect of coal ash particle size, ranging from $<0.1 \mathrm{~mm}$ to $0.4-0.5 \mathrm{~mm}$, on $\mathrm{CaO}$ conversion was investigated and the experimental data are shown in Figure 5. As expected, the difference on $\mathrm{CaO}$ conversion for pure lime and its mixtures with changing particle size of coal ash was small, and all 
showed a continuous decrease of conversion with cycle number. Turning now to carbonation conversion of mixtures consisting of SolGel and coal-derived ash (Y), the reduction of $\mathrm{CaO}$ conversion caused by the addition of coal ash can still be seen. However, it was interesting to find a decreasing detrimental effect of ash on the reactivity of $\mathrm{CaO}$ as particle size of coal ash increasing from $<0.1 \mathrm{~mm}$ to $0.4-0.5 \mathrm{~mm}$. CaO conversion of SY30_<0.1 was 0.22 in the $15^{\text {th }}$ carbonation reaction, while SY30_0.2-0.3 and SY30_0.4-0.5 showed a carbonation extent of 23\% and 26\%, respectively. This could possibly be due to a more uniform solid-solid contact between the coal ash with smaller size and the sorbent. These results suggest that suitable particle size of coal ash could reduce the occurrence of its inhibition on the carbonation of $\mathrm{CaO}$ with $\mathrm{CO}_{2}$. Fortunately, ash with smaller size is relatively easier to be separated from the fluidised bed reactor through the cyclone, in comparison with larger particles [37].

Figure 5. Effect of particle size of coal ash on carbonation conversion of $\mathrm{CaO}$. Testing conditions: carbonation in 15 vol. $\% \mathrm{CO}_{2}$ at $650{ }^{\circ} \mathrm{C}$, calcination in 100 vol. $\% \mathrm{~N}_{2}$ at $900{ }^{\circ} \mathrm{C}$, both for $10 \mathrm{~min}$.

\subsection{Effect of Severe Calcination on Carbonation}

Regeneration of $\mathrm{CaO}$-based sorbents should occur at temperatures much higher than $900{ }^{\circ} \mathrm{C}$ in a relatively pure $\mathrm{CO}_{2}$ stream if the calcium looping process is operated to separate $\mathrm{CO}_{2}$ from flue gas. Therefore, a series of experiments with pure lime, SolGel, and their mixtures with coal ash were conducted under calcination conditions of $950{ }^{\circ} \mathrm{C}$ and $100 \% \mathrm{CO}_{2}$ atmosphere. Figure 6 demonstrates the change of carbonation conversion with cycle number under the severe calcination conditions. For comparison, testing results under mild calcination conditions are also presented. The initial carbonation conversion of pure lime was 0.37 under severe calcination conditions, indicating a degradation of $31 \%$ from 0.54 measured under mild calcination. The degradation of carbonation 
conversion tends to become smaller in the following cycles and a reduction of only $18 \%$ ( 0.2 vs. 0.16) was observed after 15 cycles. Additionally, $\mathrm{CaO}$ conversion of lime and the lime/coal ash mixture had almost identical profiles as a function of cycle number, regardless of the mild or severe calcination implemented. SolGel, by contrast, demonstrated a more pronounced impact in the shifting from mild to more severe calcination conditions, and the reduction of carbonation conversion caused by coal ash addition can be observed from the $1^{\text {st }}$ to the last cycle. The results imply that calcination condition was not a major factor affecting the interaction between coal ash and $\mathrm{CaO}-$ based sorbents for $\mathrm{CO}_{2}$ capture during cyclic calcination and carbonation.

Figure 6. Carbonation conversion of sorbents under mild and severe calcination conditions. Testing conditions: carbonation in 15 vol. $\% \mathrm{CO}_{2}$ at $650{ }^{\circ} \mathrm{C}$, mild calcination in $100 \% \mathrm{~N}_{2}$ at $900{ }^{\circ} \mathrm{C}$ while severe calcination in $100 \% \mathrm{CO}_{2}$ at $950{ }^{\circ} \mathrm{C}$, all for $10 \mathrm{~min}$.

\subsection{Characterisation and Discussion}

The results described above clearly demonstrated that coal-derived ash can affect $\mathrm{CO}_{2}$ sorption performance of sorbents during cyclic reactions of calcination and carbonation, but the extent of impact varied according to the sorbents. The interaction between coal ash and $\mathrm{CaO}$-based sorbents may occur in chemical or physical aspect. To investigate the potential chemical interactions, XRD results of five samples were presented in Figure 7. It shows that $\mathrm{CaO}$ and $\mathrm{Ca}(\mathrm{OH})_{2}$ are the main compounds in lime and beyond those, there is $\mathrm{MgO}$ in SolGel. The strongest peak demonstrated in coal ash is $\mathrm{SiO}_{2}$, and other compounds of $\mathrm{Ca}_{3} \mathrm{Al}_{2} \mathrm{O}_{6}$ and $\mathrm{Ca}_{2}\left(\mathrm{Al}(\mathrm{AlSi}) \mathrm{O}_{7}\right)$ are observed as well. In the sorbent-ash mixtures, however, no new compounds is detected under the conditions studied. Therefore, here we speculate that chemical consumption of active $\mathrm{CaO}$ is not the dominant reason for the different resistance of sorbents to coal ash, basing on the facts: (1) coal ashes are measured to 
have no $\mathrm{CO}_{2}$ sorption capacity, though experimental results are not presented; (2) the main difference between lime and SolGel is that the latter contains 25 wt. \% MgO. However, no chemical reactions between $\mathrm{MgO}$ and the components from coal ash are found in Figure 7, which agrees with the results in the literature $[33,38-40]$.

Figure 7. XRD patterns of selected samples after 10 min calcination at $900{ }^{\circ} \mathrm{C}$.

To understand the physical interactions between coal ash and sorbents, $\mathrm{N}_{2}$ adsorption/desorption was utilised to measure structural parameters of freshly calcined lime, SolGel, their mixtures containing 60 wt. \% Yaan (Y) coal ash, and ash Y. The BET surface area, the BJH desorption (cumulative) of pores, the average pore diameter, and the pore diameter distribution are summarised in Figures 8 and 9. From Figure 8, it can be seen that BET surface area and BJH pore volume of pure lime are $22.32 \mathrm{~m}^{2} / \mathrm{g}$ and $0.1146 \mathrm{~cm}^{3} / \mathrm{g}$, respectively. It is well known that calcination of natural limestone usually yields a porous structure due to $\mathrm{CO}_{2}$ diffusion following the disintegration of calcite crystals into small lime crystals [41]. BET surface area of the lime used in the work is very close to the commonly reported data of calcined limestone, ranging from around 3 to just above 20 $\mathrm{m}^{2} / \mathrm{g}[11,42-46]$, while SolGel exhibits a superior surface area of $56.14 \mathrm{~m}^{2} / \mathrm{g}$. By comparing BET surface area of two sorbents, ash Y and their mixtures, it is clear that the presence of coal ash results in a large loss in the BET surface area of both initial sorbents and ash, implying there should be a synergy effect between the $\mathrm{CO}_{2}$ sorbent material and coal ash. Figure 9 shows that both the lime and SolGel have two main types of pores. Pores named type 1 are very small, with a diameter between 3-8 $\mathrm{nm}$ for lime, while is mainly $<4 \mathrm{~nm}$ for SolGel. Pores type 2 are approximately 50-80 $\mathrm{nm}$ in diameter. With 60 wt. \% coal ash in LY60_<0.1, its pore diameter distribution curve is similar to that of the original lime, but there is a loss of approximately $60-70 \%$ of the surface area and pore volume, 
as shown in Figure 8 and 9. In contrast, the pores with a diameter $<3 \mathrm{~nm}$ all disappeared for SolGel mixed with the same amount of coal ash, resulting a more pronounced decay (higher than $80 \%$ ) in surface area and pore volume, which are $4.71 \mathrm{~m}^{2} / \mathrm{g}$ and $0.0207 \mathrm{~cm}^{3} / \mathrm{g}$ for SY60_<0.1. Therefore, the pores $<3 \mathrm{~nm}$ is believed to be the most important factor for the interaction between coal ash and CaO-based sorbents.

Figure 8. Pore structure parameters of five samples after calcination for $10 \mathrm{~min}$ at $900{ }^{\circ} \mathrm{C}$.

Figure 9. Pore diameter distribution of calcined lime, SolGel and their mixtures with coal ash (Y).

Variation in sorbent morphological structure as a result of ash addition was further investigated by SEM (Figure 10). It can be seen that freshly calcined lime has a well-defined, homogeneous distribution of spherical grains close to $200 \mathrm{~nm}$ in diameter. Adding coal ash into lime caused only minimal grain growth. Compared to pure lime, SolGel grains were smaller but very close to each other. Moreover, the addition of coal ash resulted in a significant change of SolGel's morphology. Though few small grains with good porosity could still be observed, more of them disappear through mergence with the production of a more coarse and heterogeneous structure.

Figure 10. SEM images showing morphology of calcined sorbents with and without coal ash.

Figure 11. Schematic representation of pore-and-grain variation of lime and SolGel with the existence of coal ash.

Based on the above results, a schematic representation of the physical interaction between coal ash and $\mathrm{CaO}$-based sorbents is proposed, as shown in Figure 11. It is known that the introduction of coal ash can change porous structure of $\mathrm{CaO}$-based sorbents with the decline in surface area and pore 
volume. However, the variation of type 1 pores especially those below around $3 \mathrm{~nm}$ is thought to play the most critical role, as these pores are the main contributor for the surface area and pore volume of a material. Once coal ash is presented, the majority of micro-pores in SolGel is blocked, which largely reduces the accessibility of $\mathrm{CO}_{2}$ to active sorbent sites and the subsequent internal diffusibility, thus resulting in a more pronounced $\mathrm{CaO}$ reactivity loss than the lime. Additionally, ash deposition is also able to cause grain agglomeration along the surrounding sorbent and ash because of its adhesive properties. $\mathrm{CaO}$ grains in lime are characterised with more regular spherical shape and better separation from each other. Conversely, SolGel grains were observed to be connected and agglomerated with less obvious individuality than that of the lime. After the blockage of the micro-pores, the grains in SolGel can be easily bridged together in clumps with smooth surface and evident loss in porosity while there is coal ash with propensity of melting and adhesivity. Similar changes in morphological structure have also been reported in the literature [35].

The impact of coal-derived ash on calcium looping should be of concern. Even though its inhibition on $\mathrm{CO}_{2}$ sorption of sorbents can be minimised by a careful selection of both coals and sorbents, transportation of ash with sorbents in the interconnected fluidised bed, which was proposed to be the best candidate for calcium looping, and temperature maintenance of the large amount of needless material would lead to consumption of a large amount of energy. Therefore, it would be interesting to investigate the optimum combination of particles of sorbents and coals, aiming to realize an efficient separation of coal ash from the main stream of solid sorbents using a cyclone.

\section{CONCLUSIONS}

Calcium looping is a technically and economically competitive approach in mitigating $\mathrm{CO}_{2}$ emissions from coal-fired power plants. The long-term stability in sorption capacity of CaO-based sorbents is a key parameter determining the operating efficiency of the $\mathrm{CO}_{2}$ capture system, which 
can be easily affected by the ash from coal combustion in the calciner. In this work, we investigated the impact and role of several variables (sorbent type, ash content, particle size of ash, and the calcination conditions) on $\mathrm{CO}_{2}$ sorption capacity in cyclic calcination and carbonation via a thermogravimetric analyzer. The resistance to ash's negative impact is observed to be very different, largely depending on the type of sorbent used (natural or synthetic sorbent). However, the increase of ash content in sorbents and the reduction in particle size of coal ash resulted in a generally lower carbonation conversion; thus, the influence of calcination conditions on the interaction between coal ash and $\mathrm{CaO}$-based sorbents could be ignored. Physical blockage of pores (especially those with a diameter $<3 \mathrm{~nm}$, probably due to ash deposition and subsequent agglomeration) is thought to be the main contributor for the inhibition of $\mathrm{CaO}$-based sorbents with respect to their $\mathrm{CO}_{2}$ carrying capacity.

\section{ACKNOWLEDGEMENTS}

The authors are grateful to the financial supports from the National Natural Science Foundation of China (No. 51606018), China Postdoctoral Science Foundation (No. 2015M572448), Chongqing Postdoctoral Funding Project (No. Xm2015002), the Fundamental Research Funds for the Central Universities (No. 106112015CDJXY140005), Key Laboratory of Low-grade Energy Utilization Technologies and Systems of Ministry of Education (No. LLEUTS-2016004, LLEUTS-201411), and the Scientific Research Foundation for the Returned Overseas Chinese Scholars, State Education Ministry.

\section{REFERENCES}

[1] N. Rodriguez, R. Murillo, J.C. Abanades, $\mathrm{CO}_{2}$ capture from cement plants using oxyfired precalcination and/or calcium looping, Environ. Sci. Technol. 46 (2012) 2460-2466. 
[2] A. Samanta, A. Zhao, G.K.H. Shimizu, P. Sarkar, R. Gupta, Post-Combustion $\mathrm{CO}_{2}$ Capture Using Solid Sorbents: A Review, Ind. Eng. Chem. Res. 51 (2011) 1438-1463.

[3] S. Dobner, L. Sterns, R.A. Graff, A.M. Squires, Cyclic Calcination and Recarbonation of Calcined Dolomite, Ind. Eng. Chem. Process Des. Dev. 16 (1977) 479-486.

[4] D.Y. Lu, R.W. Hughes, E.J. Anthony, Ca-based sorbent looping combustion for $\mathrm{CO}_{2}$ capture in pilot-scale dual fluidized beds, Fuel Process. Technol. 89 (2008) 1386-1395.

[5] L.S. Fan, L. Zeng, W.L. Wang, S.W. Luo, Chemical Looping Processes for $\mathrm{CO}_{2}$ Capture and Carbonaceous Fuel Conversion-Prospect and Opportunity, Energy Environ. Sci. 5 (2012) 7254-7280.

[6] M. Zhao, A.I. Minett, A.T. Harris, A review of techno-economic models for the retrofitting of conventional pulverised-coal power plants for post-combustion capture (PCC) of $\mathrm{CO}_{2}$, Energy Environ. Sci. 6 (2013) $25-40$.

[7] A.B. Rao, E.S. Rubin, A Technical, Economic, and Environmental Assessment of Amine-Based $\mathrm{CO}_{2} \mathrm{Capture}$ Technology for Power Plant Greenhouse Gas Control, Environ. Sci. Technol. 36 (2002) 4467-4475.

[8] C. Luo, Y. Zheng, C. Zheng, J. Yin, C. Qin, B. Feng, Manufacture of calcium-based sorbents for high temperature cyclic $\mathrm{CO}_{2}$ capture via a sol-gel process, Int. J. Greenhouse Gas Control 12 (2013) 193-199.

[9] Y. Wu, V. Manovic, I. He, E.J. Anthony, Modified lime-based pellet sorbents for high-temperature $\mathrm{CO}_{2}$ capture: Reactivity and attrition behavior, Fuel 96 (2012) 454-461.

[10] C. Qin, W. Liu, H. An, J. Yin, B. Feng, Fabrication of CaO-Based Sorbents for $\mathrm{CO}_{2}$ Capture by a Mixing Method, Environ. Sci. Technol. 46 (2012) 1932-1939.

[11] R. Sun, Y. Li, S. Wu, C. Liu, H. Liu, C. Lu, Enhancement of $\mathrm{CO}_{2}$ capture capacity by modifying limestone with propionic acid, Powder Technol. 233 (2013) 8-14.

[12] R. Koirala, G.K. Reddy, P.G. Smirniotis, Single Nozzle Flame-Made Highly Durable Metal Doped Ca-Based Sorbents for $\mathrm{CO}_{2}$ Capture at High Temperature, Energy Fuels 26 (2012) 3103-3109.

[13] Y. Hu, W. Liu, J. Sun, M. Li, X. Yang, Y. Zhang, M. Xu, Incorporation of $\mathrm{CaO}$ into novel $\mathrm{Nd}_{2} \mathrm{O}_{3}$ inert solid 
support for high temperature $\mathrm{CO}_{2}$ capture, Chem. Eng. J. 273 (2015) 333-343.

[14] A. Akgsornpeak, T. Witoon, T. Mungcharoen, J. Limtrakul, Development of synthetic CaO sorbents via CTAB-assisted sol-gel method for $\mathrm{CO}_{2}$ capture at high temperature, Chem. Eng. J. 237 (2014) 189-198.

[15] T. Witoon, T. Mungcharoen, J. Limtrakul, Biotemplated synthesis of highly stable calcium-based sorbents for $\mathrm{CO}_{2}$ capture via a precipitation method, Appl. Energy 118 (2014) 32-40.

[16] A.M. Kierzkowska, L.V. Poulikakos, M. Broda, C.R. Müller, Synthesis of calcium-based, $\mathrm{Al}_{2} \mathrm{O}_{3}$-stabilized sorbents for $\mathrm{CO}_{2}$ capture using a co-precipitation technique, Int. J. Greenhouse Gas Control 15 (2013) 48-54.

[17] H. Chen, C. Zhao, Development of a CaO-based sorbent with improved cyclic stability for $\mathrm{CO}_{2}$ capture in pressurized carbonation, Chem. Eng. J. 171 (2011) 197-205.

[18] H. Chen, C. Zhao, Y. Yang, Enhancement of attrition resistance and cyclic $\mathrm{CO}_{2}$ capture of calcium-based sorbent pellets, Fuel Process. Technol. 116 (2013) 116-122.

[19] C. Luo, Y. Zheng, J. Yin, C. Qin, N. Ding, C. Zheng, B. Feng, Effect of Support Material on Carbonation and Sulfation of Synthetic CaO-Based Sorbents in Calcium Looping Cycle, Energy Fuels 27 (2013) 4824-4831.

[20] R.W. Hughes, D.Y. Lu, E.J. Anthony, A. Macchi, Design, Process Simulation and Construction of An Atmospheric Dual Fluidized Bed Combustion System for In Situ $\mathrm{CO}_{2}$ Capture Using High-Temperature Sorbents, Fuel Process. Technol. 86 (2005) 1523-1531.

[21] W. Wang, S. Ramkumar, S. Li, D. Wong, M. Iyer, B.B. Sakadjian, R.M. Statnick, L.S. Fan, Subpilot Demonstration of the Carbonation-Calcination Reaction (CCR) Process: High-Temperature $\mathrm{CO}_{2}$ and Sulfur Capture from Coal-Fired Power Plants, Ind. Eng. Chem. Res. 49 (2010) 5094-5101.

[22] S. Koppatz, C. Pfeifer, R. Rauch, H. Hofbauer, T. Marquard-Moellenstedt, M. Specht, $\mathrm{H}_{2}$ rich product gas by steam gasification of biomass with in situ $\mathrm{CO}_{2}$ absorption in a dual fluidized bed system of $8 \mathrm{MW}$ fuel input, Fuel Process. Technol. 90 (2009) 914-921.

[23] A. Charitos, N. Rodríguez, C. Hawthorne, M. Alonso, M. Zieba, B. Arias, G. Kopanakis, G. Scheffknecht, J.C. Abanades, Experimental Validation of the Calcium Looping $\mathrm{CO}_{2}$ Capture Process with Two Circulating 
Fluidized Bed Carbonator Reactors, Ind. Eng. Chem. Res. 50 (2011) 9685-9695.

[24] N. Rodríguez, M. Alonso, J.C. Abanades, Experimental Investigation of A Circulating Fluidized-Bed Reactor to Capture $\mathrm{CO}_{2}$ with $\mathrm{CaO}$, AICHE J. 57 (2011) 1356-1366.

[25] M.H. Chang, C.M. Huang, W.H. Liu, W.C. Chen, J.Y. Cheng, W. Chen, T.W. Wen, S. Ouyang, C.H. Shen, H.W. Hsu, Design and Experimental Investigation of Calcium Looping Process for 3-kWth and 1.9-MW Facilities, Chem. Eng. Technol. 36 (2013) 1525-1532.

[26] B. Arias, M.E. Diego, J.C. Abanades, M. Lorenzo, L. Diaz, D. Martínez, J. Alvarez, A. Sánchez-Biezma, Demonstration of steady state $\mathrm{CO}_{2}$ capture in a $1.7 \mathrm{MW}_{\text {th }}$ calcium looping pilot, Int. J. Greenhouse Gas Control 18 (2013) 237-245.

[27] V. Materić, R. Symonds, D. Lu, R. Holt, V. Manović, Performance of Hydration Reactivated Ca Looping Sorbents in a Pilot-Scale, Oxy-fired Dual Fluid Bed Unit, Energy Fuels 28 (2014) 5363-5372.

[28] D.P. Hanak, E.J. Anthony, V. Manovic, A review of developments in pilot-plant testing and modelling of calcium looping process for $\mathrm{CO}_{2}$ capture from power generation systems, Energy Environ. Sci. 8 (2015) 2199-2249.

[29] J. Ströhle, M. Junk, J. Kremer, A. Galloy, B. Epple, Carbonate looping experiments in a 1 MWth pilot plant and model validation, Fuel 127 (2014) 13-22.

[30] J. Blamey, E.J. Anthony, J. Wang, P.S. Fennell, The calcium looping cycle for large-scale $\mathrm{CO}_{2}$ capture, Prog. Energy Combust. Sci. 36 (2010) 260-279.

[31] B.R. Stanmore, P. Gilot, Review--calcination and carbonation of limestone during thermal cycling for $\mathrm{CO}_{2}$ sequestration, Fuel Process. Technol. 86 (2005) 1707-1743.

[32] Y. Wu, V. Manovic, I. He, E.J. Anthony, Reuse of Spent Sorbents from $\mathrm{FBC}$ for $\mathrm{SO}_{2}$ Capture by Simultaneous Reactivation and Pelletization, Energy Fuels 27 (2013) 82-86.

[33] H. Katalambula, A. Bawagan, S. Takeda, Mineral attachment to calcium-based sorbent particles during in situ desulfurization in coal gasification processes, Fuel Process. Technol. 73 (2001) 75-93. 
[34] F. Fang, Z.-s. Li, N.-s. Cai, $\mathrm{CO}_{2}$ capture from flue gases using a fluidized bed reactor with limestone, Korean J. Chem. Eng. 26 (2009) 1414-1421.

[35] R.W. Hughes, A. Macchi, D.Y. Lu, E.J. Anthony, Changes in Limestone Sorbent Morphology during CaO-CaCO 3 Looping at Pilot Scale, Chem. Eng. Technol. 32 (2009) 425-434.

[36] K. Kuramoto, S. Shibano, S. Fujimoto, T. Kimura, Y. Suzuki, H. Hatano, L. Shi-Ying, M. Harada, K. Morishita, T. Takarada, Deactivation of Ca-Based Sorbents by Coal-Derived Minerals during Multicycle $\mathrm{CO}_{2}$ Sorption under Elevated Pressure and Temperature, Ind. Eng. Chem. Res. 42 (2003) 3566-3570.

[37] J. Bao, Z. Li, N. Cai, Interaction between iron-based oxygen carrier and four coal ashes during chemical looping combustion, Appl. Energy 115 (2014) 549-558.

[38] J.E. Readman, R. Blom, The use of in situ powder X-ray diffraction in the investigation of dolomite as a potential reversible high-temperature $\mathrm{CO}_{2}$ sorbent, PCCP 7 (2005) 1214-1219.

[39] C. Qin, J. Yin, W. Liu, H. An, B. Feng, Behavior of $\mathrm{CaO} / \mathrm{CuO}$ Based Composite in a Combined Calcium and Copper Chemical Looping Process, Ind. Eng. Chem. Res. 51 (2012) 12274-12281.

[40] W. Liu, B. Feng, Y. Wu, G. Wang, J. Barry, J.C.D.D. Costa, Synthesis of Sintering-Resistant Sorbents for $\mathrm{CO}_{2}$ Capture, Environ. Sci. Technol. 44 (2010) 3093-3097.

[41] J.M. Valverde, Ca-based synthetic materials with enhanced $\mathrm{CO}_{2}$ capture efficiency, Journal of Materials Chemistry A 1 (2013) 447-468.

[42] W. Wu, C. Zhao, Q. Li, W. Zhou, Experimental investigation on calcination/sulphation characteristics of limestone modified by acetic acid solution in $\mathrm{O}_{2} / \mathrm{CO}_{2}$ atmosphere, Proceedings of the Combustion Institute 33 (2011) 3455-3462.

[43] F. Donat, N.H. Florin, E.J. Anthony, P.S. Fennell, Influence of high-temperature steam on the reactivity of $\mathrm{CaO}$ sorbent for $\mathrm{CO}_{2}$ capture, Environ. Sci. Technol. 46 (2012) 1262-1269.

[44] H. Chen, Z. Zhao, X. Huang, K. Patchigolla, A. Cotton, J. Oakey, Novel Optimized Process for Utilization of CaO-Based Sorbent for Capturing $\mathrm{CO}_{2}$ and $\mathrm{SO}_{2}$ Sequentially, Energy Fuels 26 (2012) 5596-5603. 
[45] M.J. Al-Jeboori, M. Nguyen, C. Dean, P.S. Fennell, Improvement of Limestone-Based $\mathrm{CO}_{2}$ Sorbents for Ca Looping by HBr and Other Mineral Acids, Ind. Eng. Chem. Res. 52 (2013) 1426-1433.

[46] Y. Li, H. Liu, S. Wu, R. Sun, C. Lu, Sulfation behavior of $\mathrm{CaO}$ from long-term carbonation/calcination cycles for $\mathrm{CO}_{2}$ capture at FBC temperatures, J. Therm. Anal. Calorim. 111 (2013) 1335-1343. 
TABLES

Table 1. Chemical composition of calcined limestone and coal ashes.

\begin{tabular}{llll}
\hline Compound,wt. \% & Lime & Ash X & Ash Y \\
\hline $\mathrm{CaO}$ & 96.56 & 3.55 & 2.02 \\
$\mathrm{SiO}_{2}$ & 1.70 & 51.35 & 56.37 \\
$\mathrm{Al}_{2} \mathrm{O}_{3}$ & 0.60 & 26.17 & 27.74 \\
$\mathrm{Fe}_{2} \mathrm{O}_{3}$ & 0.47 & 10.52 & 5.30 \\
$\mathrm{SO}_{3}$ & 0.33 & 2.45 & 0.31 \\
$\mathrm{TiO}_{2}$ & 0.13 & 2.91 & 2.16 \\
$\mathrm{SrO}$ & 0.13 & 0.21 & 0.04 \\
$\mathrm{P}_{2} \mathrm{O}_{5}$ & 0.03 & 0.14 & 0.21 \\
$\mathrm{~K}_{2} \mathrm{O}$ & 0.03 & 1.02 & 2.61 \\
$\mathrm{MgO}$ & 0.00 & 0.73 & 2.31 \\
$\mathrm{Na}{ }_{2} \mathrm{O}$ & 0.00 & 0.43 & 0.62 \\
$\mathrm{ZrO}$ & 0.24 & 0.08 \\
$\mathrm{BaO}_{2}$ & 0.00 & 0.10 & 0.00 \\
$\mathrm{MnO}$ & 0.00 & 0.04 & 0.05 \\
$\mathrm{Cr} \mathrm{O}_{3}$ & 0.00 & 0.04 & 0.04 \\
$\mathrm{CuO}$ & 0.00 & 0.03 & 0.03 \\
$\mathrm{Y} 2 \mathrm{O}$ & 0.02 & 0.01 \\
$\mathrm{ZnO}$ & 0.00 & 0.02 & 0.04 \\
$\mathrm{NbO}$ & 0.00 & 0.02 & 0.00 \\
$\mathrm{NiO}$ & 0.00 & 0.02 & 0.03 \\
$\mathrm{Co} \mathrm{O}_{3}$ & 0.00 & 0.00 & 0.02 \\
$\mathrm{Rb}_{2} \mathrm{O}$ & 0.00 & 0.00 & 0.02 \\
$\mathrm{Total}$ & 0.00 & 100.00 & 100.00 \\
\hline
\end{tabular}




\section{FIGURES}

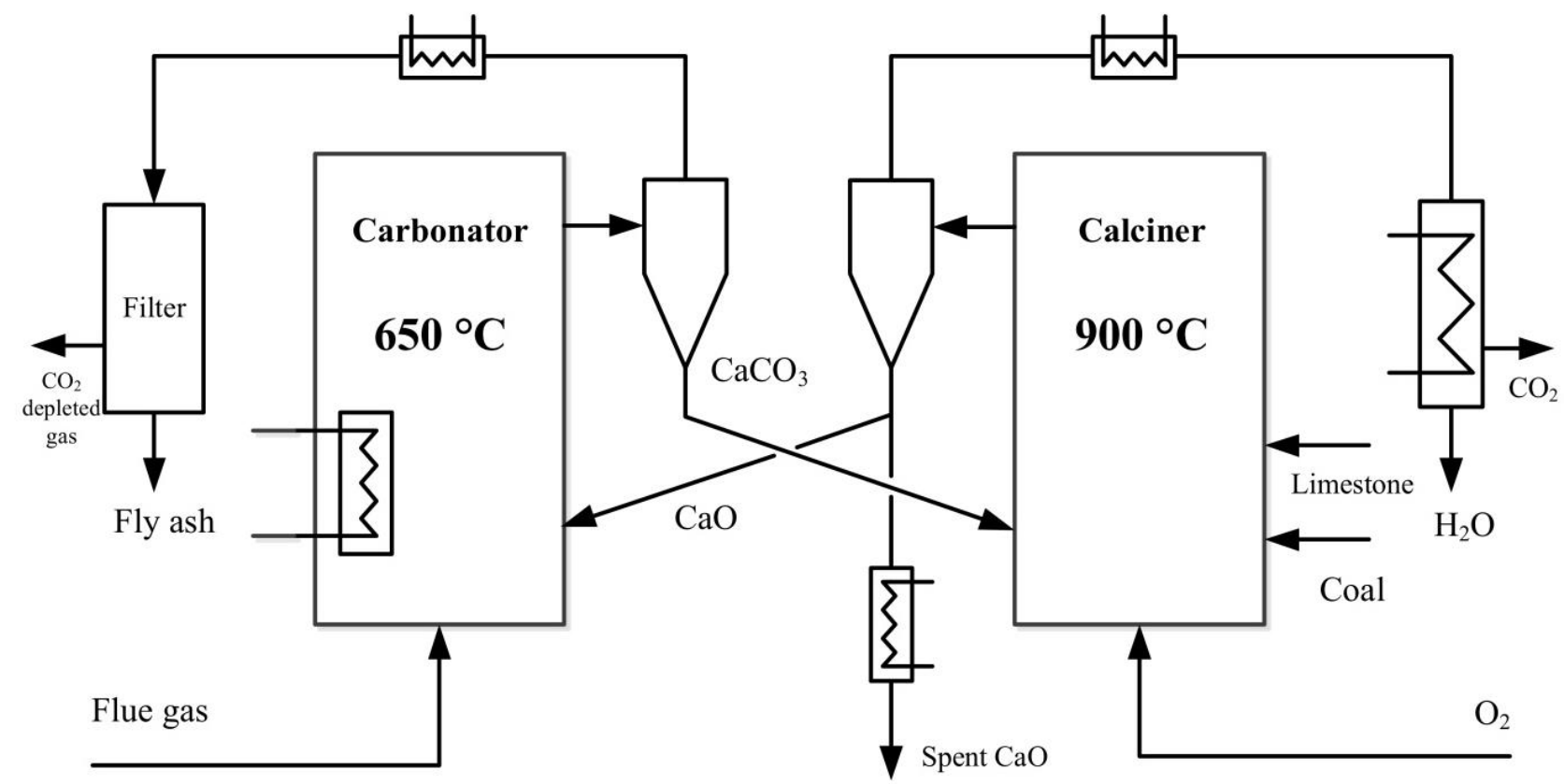

Figure 1. Schematic representation of calcium looping for $\mathrm{CO}_{2}$ capture from power plant flue gas. 

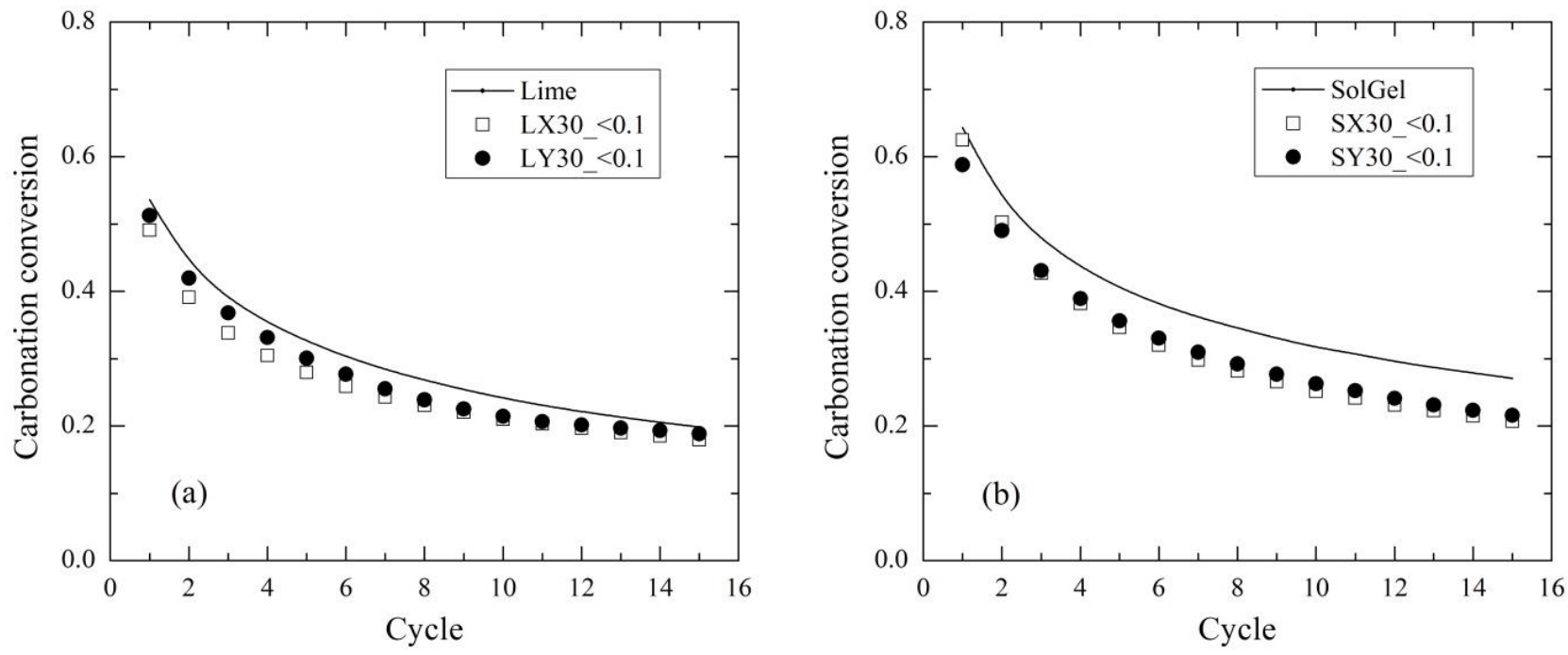

Figure 2. Repeated cycles of carbonation in presence of coal-derived ash (carbonation at $650{ }^{\circ} \mathrm{C}$ in 15 vol. $\% \mathrm{CO}_{2}$ for $10 \mathrm{~min}$, and calcination at $900{ }^{\circ} \mathrm{C}$ in pure $\mathrm{N}_{2}$ for $10 \mathrm{~min}$ ). 

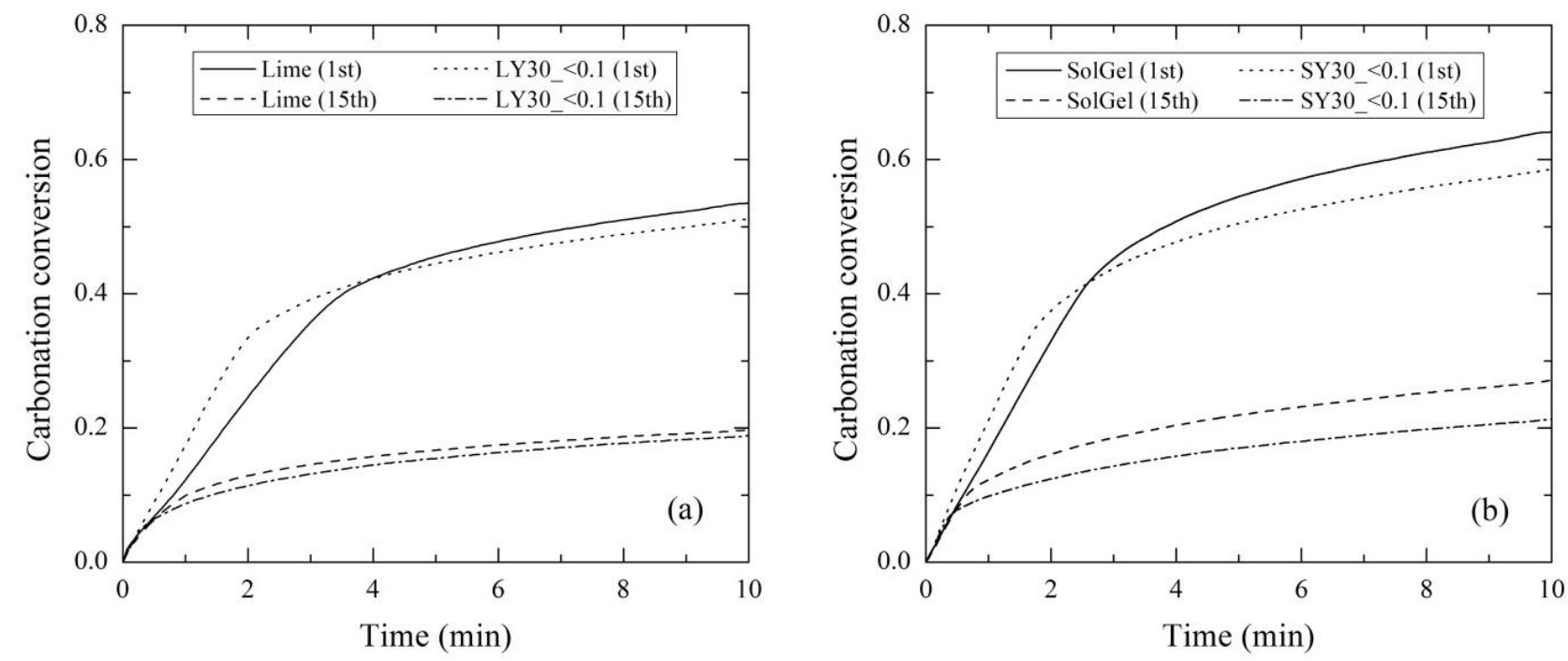

Figure 3. Carbonation as a function of time in the $1^{\text {st }}$ and $15^{\text {th }}$ cycle of CaO-based sorbents with/without coal ash at $650{ }^{\circ} \mathrm{C}$ in 15 vol. $\% \mathrm{CO}_{2}$. 

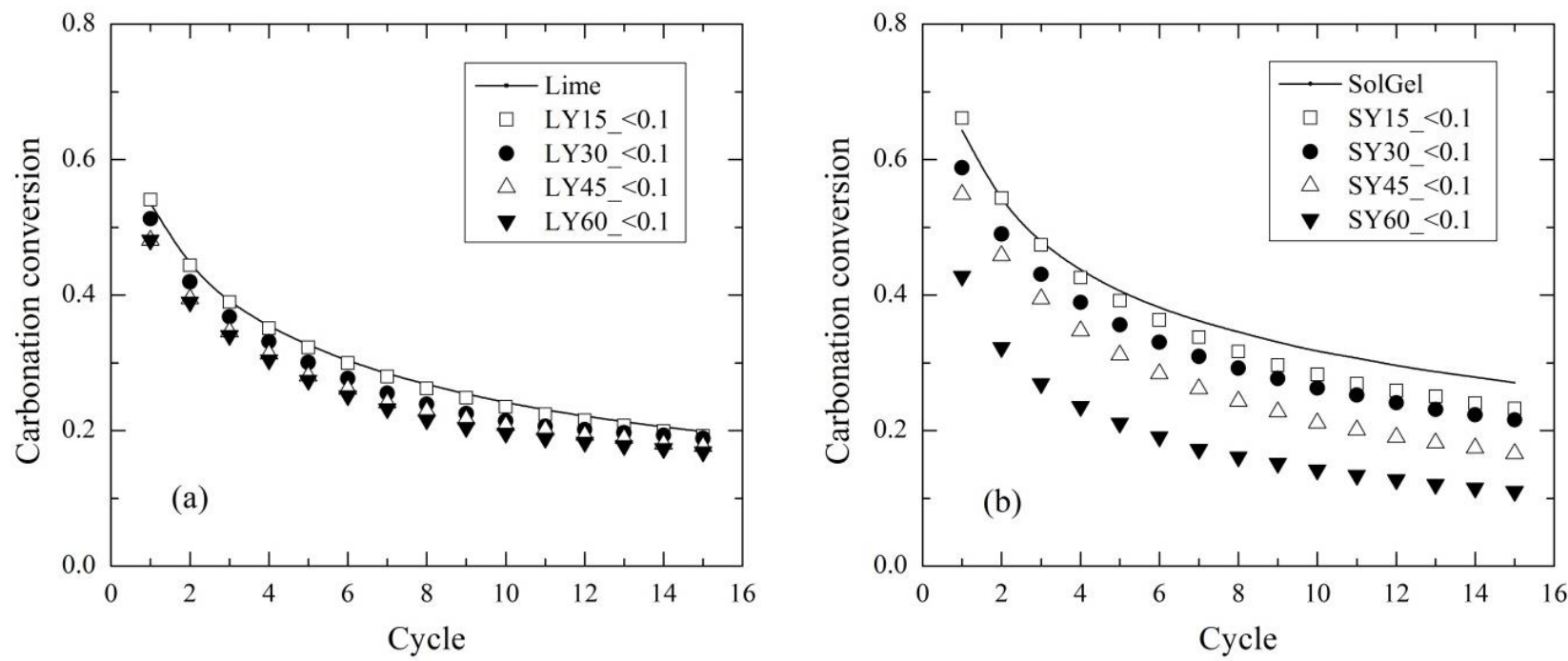

Figure 4. Effect of ash content on carbonation. Testing condition: carbonation in 15 vol. $\% \mathrm{CO}_{2}$ at $650{ }^{\circ} \mathrm{C}$, calcination in 100 vol. $\% \mathrm{~N}_{2}$ at $900{ }^{\circ} \mathrm{C}$, both for $10 \mathrm{~min}$. 

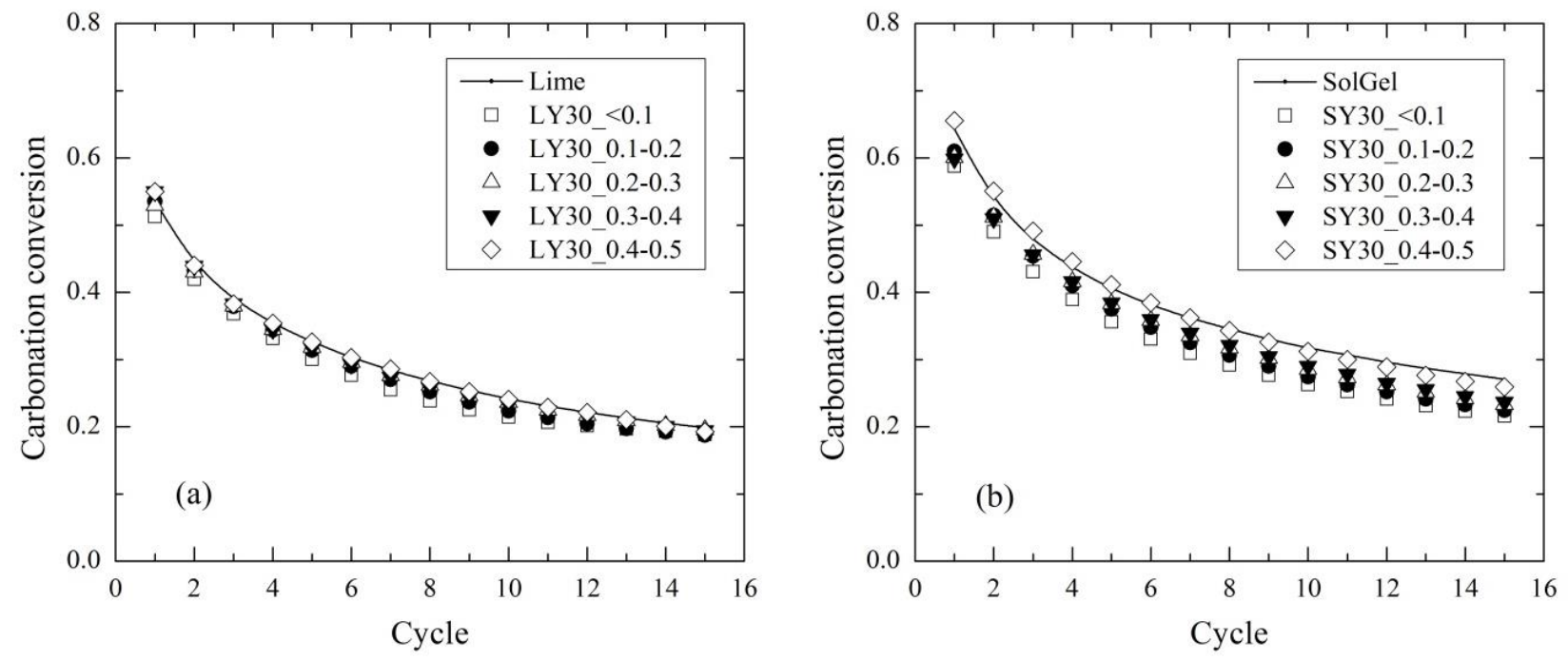

Figure 5. Effect of particle size of coal ash on carbonation conversion of $\mathrm{CaO}$. Testing conditions:

carbonation in 15 vol. $\% \mathrm{CO}_{2}$ at $650{ }^{\circ} \mathrm{C}$, calcination in 100 vol. $\% \mathrm{~N}_{2}$ at $900{ }^{\circ} \mathrm{C}$, both for $10 \mathrm{~min}$. 

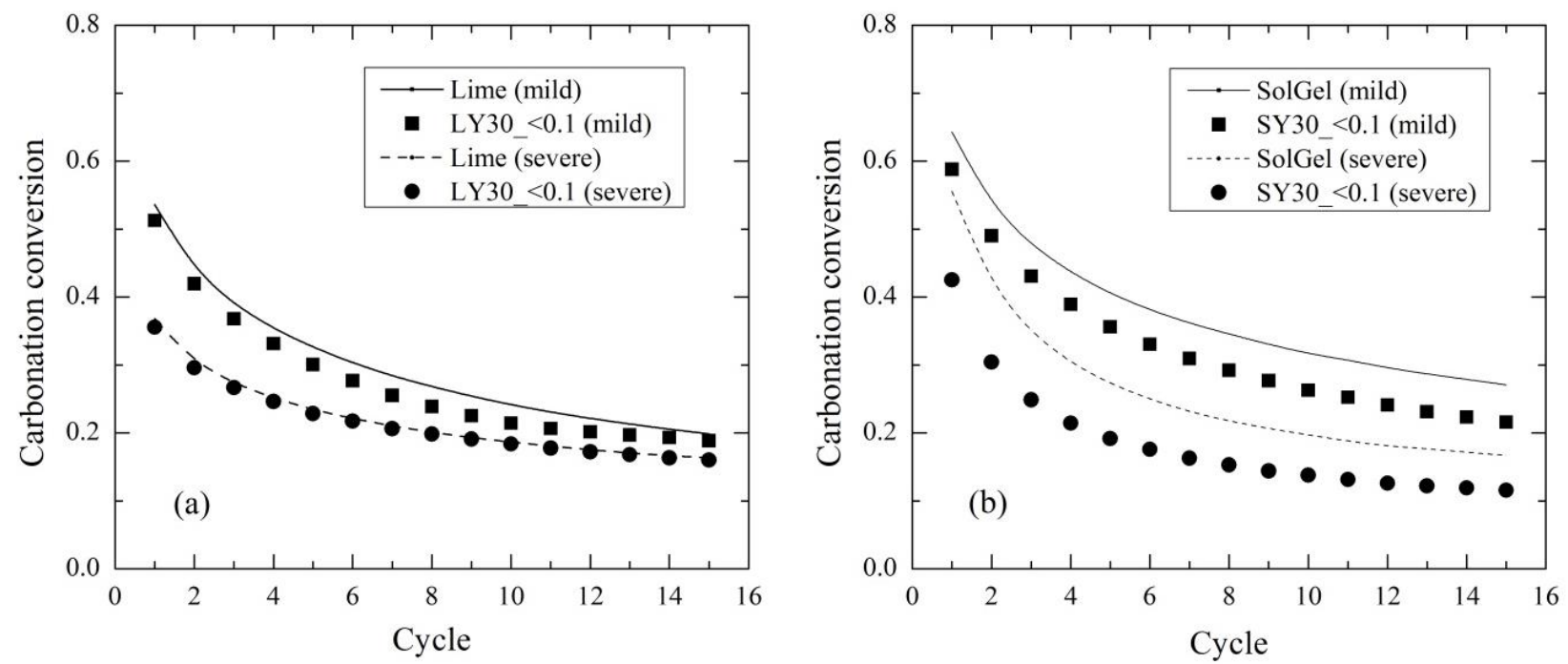

Figure 6. Carbonation conversion of sorbents under mild and severe calcination conditions. Testing conditions: carbonation in 15 vol. $\% \mathrm{CO}_{2}$ at $650{ }^{\circ} \mathrm{C}$, mild calcination in $100 \% \mathrm{~N}_{2}$ at $900{ }^{\circ} \mathrm{C}$ while severe calcination in $100 \% \mathrm{CO}_{2}$ at $950{ }^{\circ} \mathrm{C}$, all for $10 \mathrm{~min}$. 


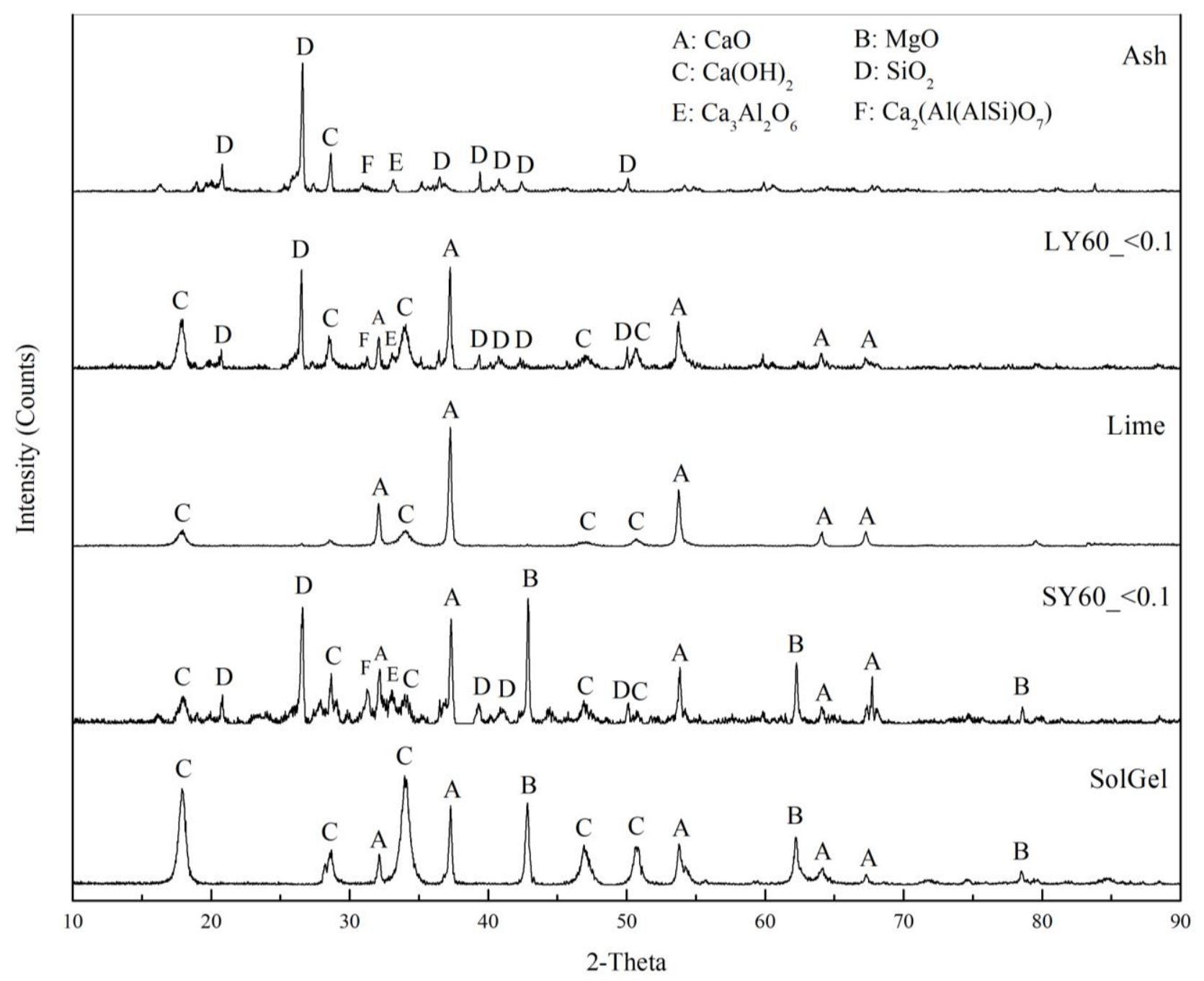

Figure 7. XRD patterns of selected samples after 10 min calcination at $900{ }^{\circ} \mathrm{C}$. 


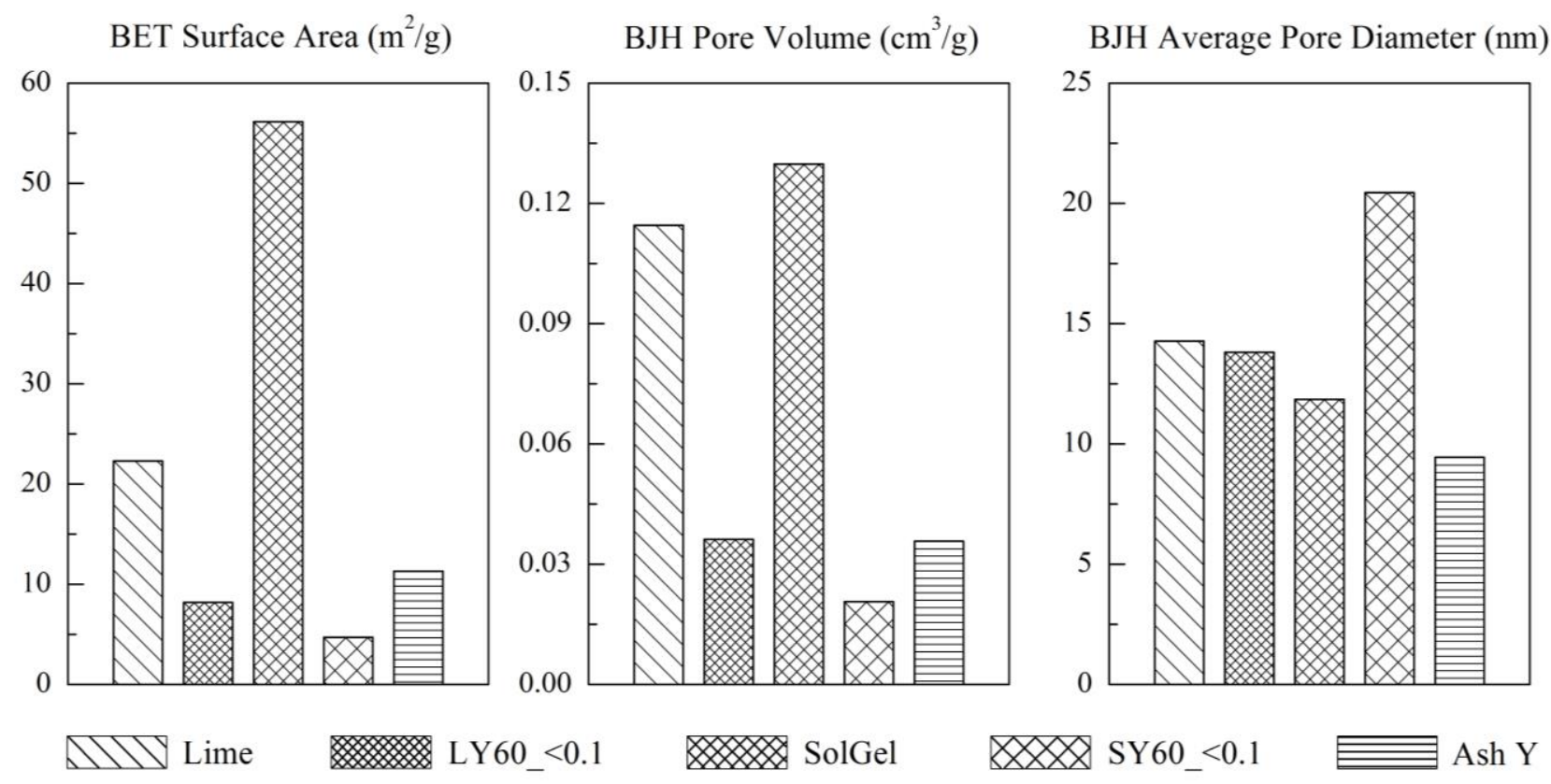

Figure 8. Pore structure parameters of five samples after calcination for $10 \mathrm{~min}$ at $900{ }^{\circ} \mathrm{C}$. 

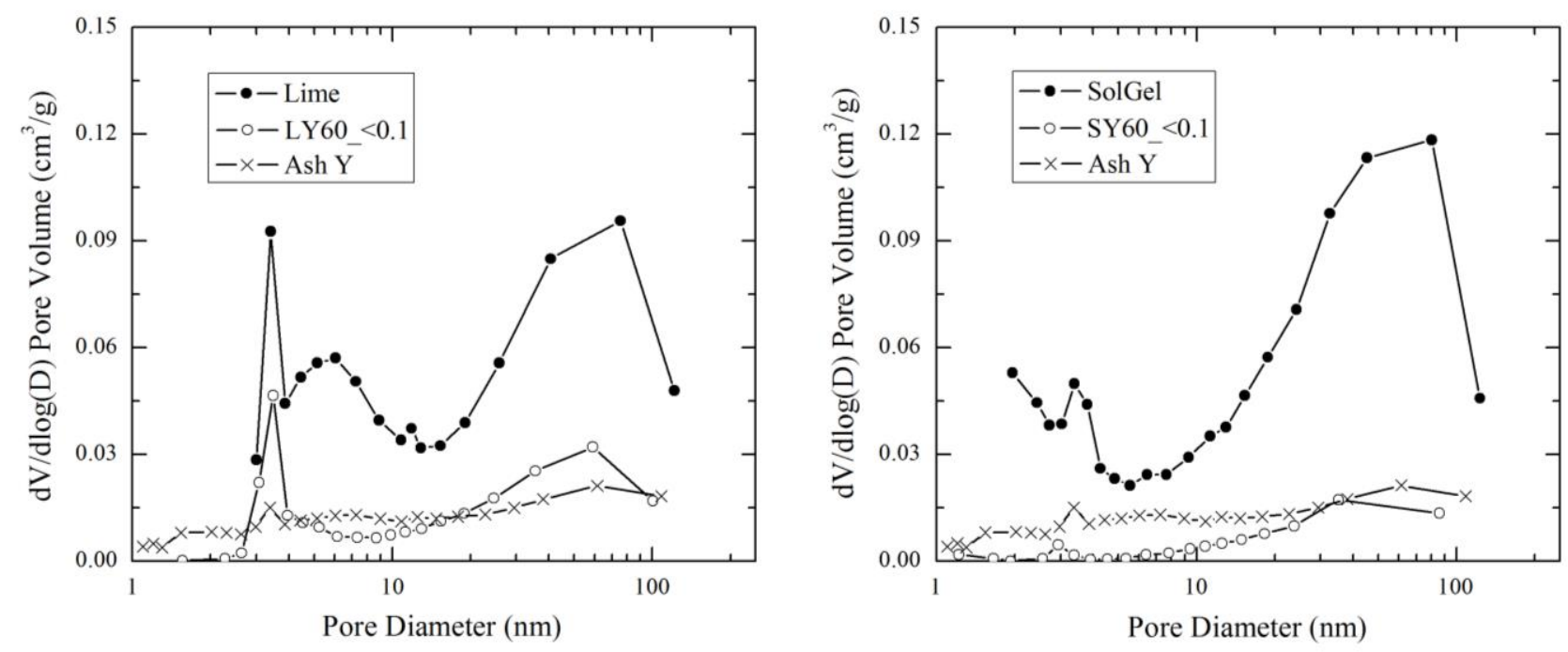

Figure 9. Pore diameter distribution of calcined lime, SolGel and their mixtures with coal ash (Y). 
Lime
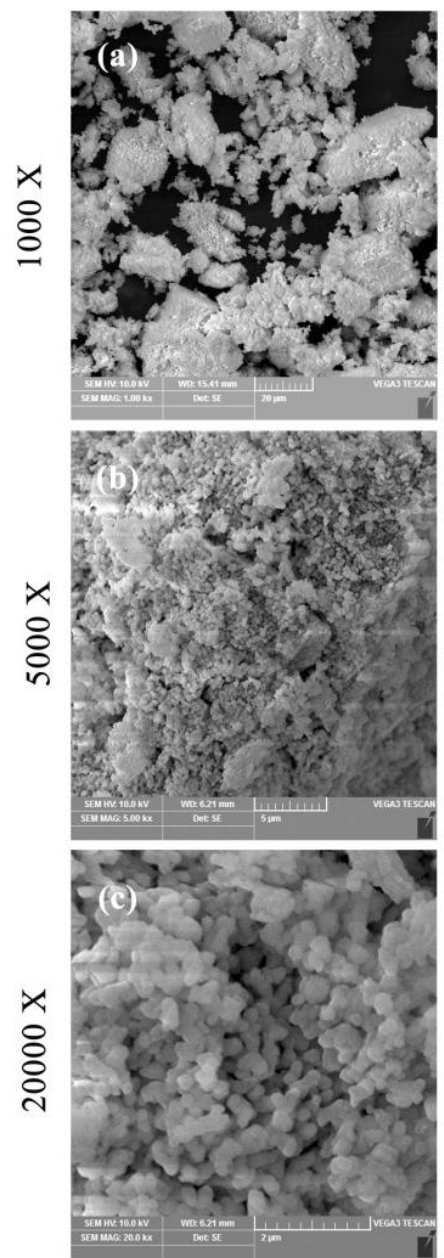

LY60_<0.1
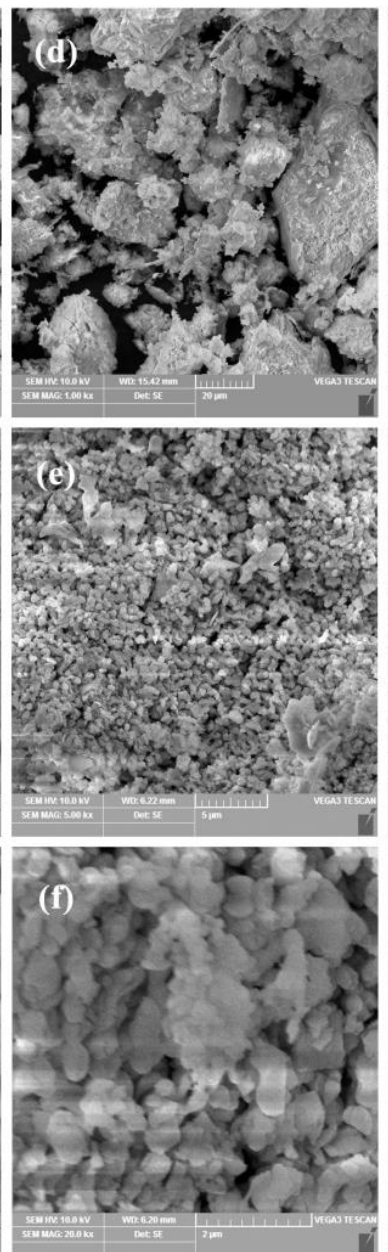

SolGel
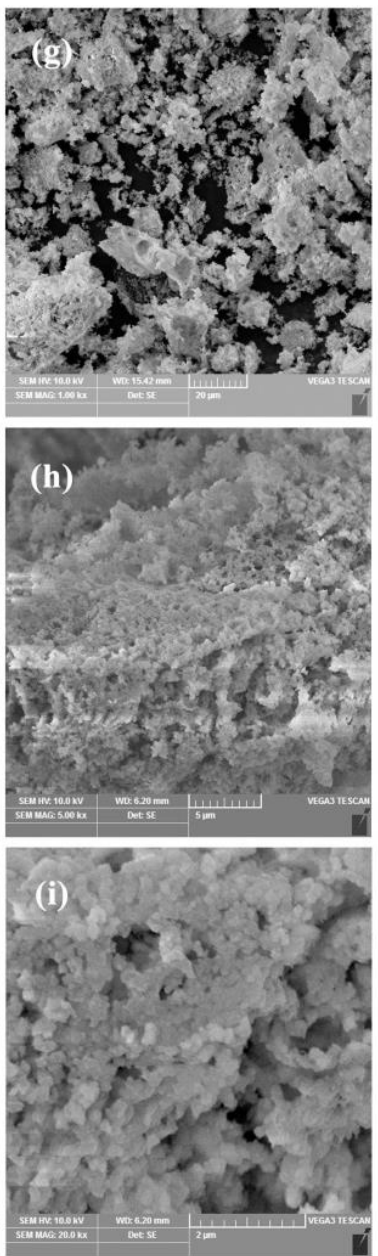

SY $60<0.1$
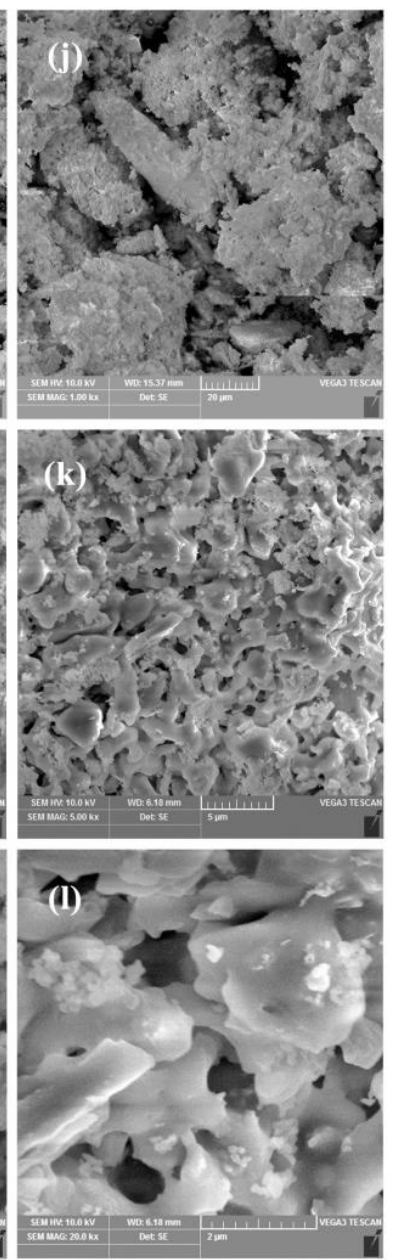

Figure 10. SEM images showing morphology of calcined sorbents with and without coal ash. 

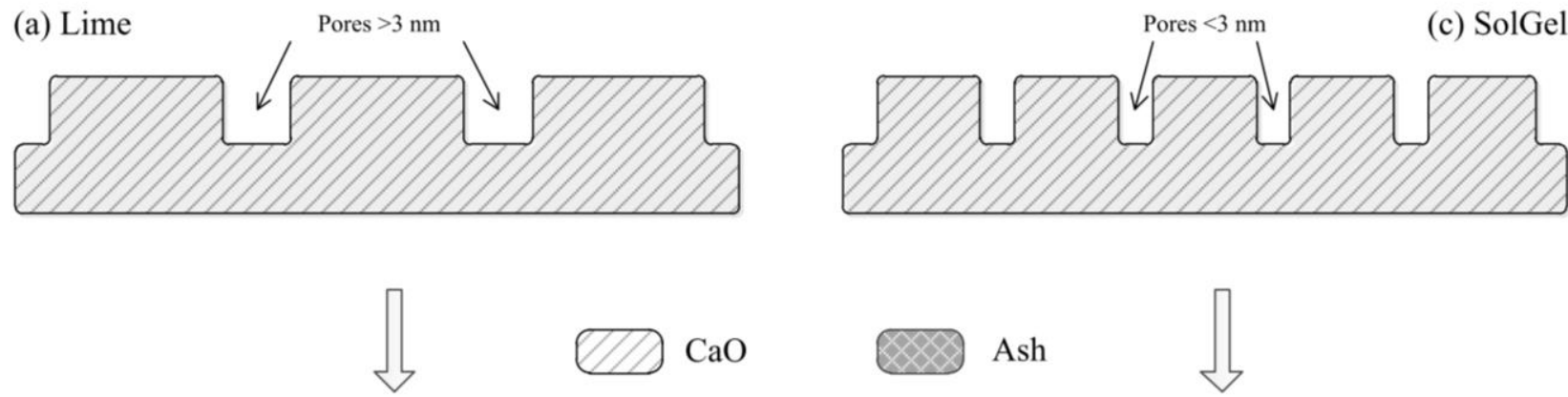

(b) Lime with ash
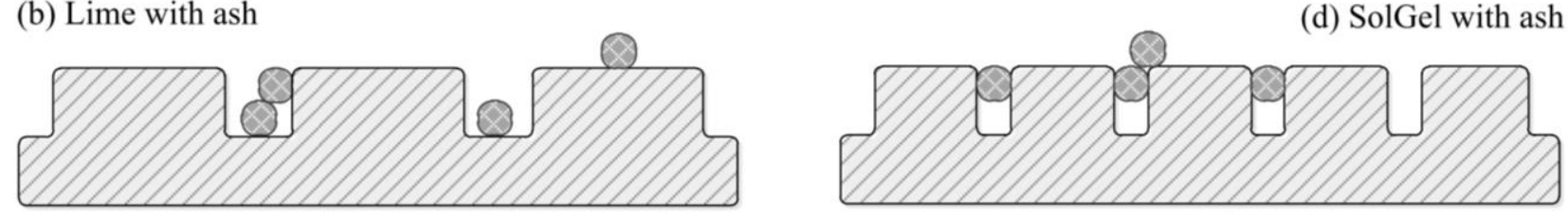

Figure 11. Schematic representation of pore-and-grain variation of lime and SolGel with the existence of coal ash. 